\title{
Gamma-Aminobutyric Acid Receptor Subunit Alpha-3
}

National Cancer Institute

\section{Source}

National Cancer Institute. Gamma-Aminobutyric Acid Receptor Subunit Alpha-3. NCl

Thesaurus. Code C126545.

Gamma-aminobutyric acid receptor subunit alpha-3 (492 aa, $\sim 55 \mathrm{kDa}$ ) is encoded by the human GABRA3 gene. This protein is involved in both ligand-gated chloride transport and the inhibition of neurotransmission. 